DOI https:/ / doi.org/10.32837/app.v0i64.190

УДК 321:316.483 (478.9+479.22+477)

Завгородня Ю. В. * (НУ «ОЮА»)

ORCID ID: https://orcid.org/0000-0003-3500-8638

Кройmop A. B. ** $(\mathrm{HY} « \mathrm{O}$

ORCID ID: https://orcid.org/0000-0003-4652-7441

Пехник А. В. ${ }^{* * *}(\mathrm{HУ}$ «ОЮА»)

ORCID ID: https://orcid.org/0000-0003-2534-7652

\title{
ОСОБЛИВОСТІ РОЗВ' ЯЗАННЯ КОНФЛІКТІВ ТА УПРАВЛІННЯ КОНФЛІКТАМИ У ПОСТРАДЯНСЬКИХ КРАЇНАХ (НА ПРИКЛАДІ МОЛДОВИ, ГРУЗЇ̈, УКРАЇНИ)
}

\section{FEATURES OF CONFLICT RESOLUTION AND CONFLICT MANAGEMENT IN POST-SOVIET COUNTRIES (ON THE EXAMPLE OF MOLDOVA, GEORGIA, UKRAINE)}

*Yuliia Zavhorodnia - PhD in Political Science, Associate Professor at the Political Theories Department, National University "Odesa Law Academy" (23, Fontanska Doroha St., Odesa, Ukraine).

**Artem Kroytor - PhD in Political Science, Associate Professor at the Political Theories Department, National University "Odesa Law Academy" (23, Fontanska Doroha St., Odesa, Ukraine).

***Alevtina Pekhnik - PhD in Political Science, Associate Professor at the Political Theories Department, National University "Odesa Law Academy" (23, Fontanska Doroha St., Odesa, Ukraine).

\section{Abstract}

A political conflict contains general signs that distinguish it from other public conflicts, and possible ways of development and overcoming conflict situations are already established on theoretical and practical levels. However, the modern history of post-soviet countries shows the danger of political conflicts, as opposing parties not always use the generally accepted rules of the diplomatic settlement 
of conflicts, and that is why there is a possibility of conflict contradictions for an indefinite period.

The features of opposing escalation on the walks of life of Moldova, Georgia, and Ukraine demonstrate the hazard effects of military conflicts, that arose upon the basis of political processes development, and that is why need attention and detailed analysis. Parties are succeeded in the unforeseeable actions, and all wellknown ways of settlement of conflicts do not result in the decision of conflicts.

Of course, the post-Soviet countries on the conflict map show specific ways of developing political conflict, its escalation and the features of suspension. Conflict resolution in post-Soviet countries often leads the parties to further aggravation. The subjects of political conflict reach a critical point of confrontation, which is armed confrontation.

During the Soviet Union, conflicts were not resolved at all, they were not publicly disclosed, and there was virtually no scientific research on the subject. With the emergence of independent post-Soviet states, political conflicts began to publicly manifest themselves in various spheres of social life, contributing to scientific activity in the conflict direction of research. Therefore, the peculiarities of the settlement of political conflict begin to illuminate in the period of the formation of independent post-Soviet states.

It has already been established that post-communist countries have a difficult transition to democracy and perceive this process differently since some have been left indefinitely, others have quickly changed to a new order, and others cannot determine the vector of development. This process is interpreted by scientists as inconsistent, contradictory and careless.

Keywords: political conflict, diplomacy, voice process, secession, cold world, compromise, collaboration, Transnistria, South Ossetia, Donbass.

Конфлікт на політичній арені виникає у зв'язку з протиріччям між окремими суб'єктами та потребує дієвого шляху врегулювання вигідного, в першу чергу, для громадян, а потім для політичних сил. Адже, суб'єкти політики у прийнятті будь якого рішення зобов'язанні керуватися інтересами населення, а вектор їх дій має уособлювати погляди громадян, яких вони представляють.

Питання щодо розв'язання політичних конфліктів досліджували вітчизняні та зарубіжні автори, а саме: А. Кройтор, Ю. Завгородня, В. Мандрагеля, Л. Герасимва, М. Панова, О. Сахань, Ю. Шайгородський та ін.

Враховуючи основні історичні та практичні особливості транзиту пост радянських держав, варто звернути увагу на сучасне покоління 
людей посттоталітарної країни, яке не має геополітичних кордонів, вільно говорить про політичні процеси, критикує чи підтримує політичну еліту, а найголовніше бажає вільного вибору в усіх суспільнополітичних процесах. Молоде покоління, Молдови, Грузії та України має спільні цілі та бажання, щодо територіальної цілісності та незалежності, а рішення сучасної політичної еліти не відповідають бажанням та прагненням громадян.

А тому метою наукового дослідження $є$ проведення порівняльного аналізу трьох суспільно-значимих політичних конфліктів у країнах Молдови, Грузії та України, для виявлення ключових причин розвитку конфліктів їх протікання та можливих шляхів врегулювання.

Тому, правляча політична еліта намагається обійти бажання сучасних громадян і продовжувати управління суспільством за допомогою тоталітарної форми, що породжує стару проблему приховування конфліктів, відведення від конфліктів, замовчування конфліктів.

Окрім того, варто пам'ятати, що значний впив на консервування політичних конфліктів на державному рівні здійснює міжнародне співтовариство, з метою зменшення масштабів територіального протиборства та недопущення до світових війн сучасності. Щоб наслідки регіонального протиборства не торкнулися світових масштабів. Сучасна глобалізаційна політика, щодо вирішення політичних конфліктів, націлена на мирне компромісне врегулювання політичних конфліктів.

Для освідомлення компромісного механізму взаємодії між суб'єктами протиборства потрібно визначити рівень конфлікту. За своєю сутністю політичний конфлікт може відбуватися на двох рівнях: по перше, це всередині соціальних груп та політичних груп, які є частиною влади, але мають бажання володіти більшими можливостями чи повноваженнями влади, з метою повного задоволення власних інтересів; по друге, між політичними групами і соціальними групами, які в сучасний період часу не є частиною влади, однак мають бажання отримати владу та заволодіти силою над групами, які контролюють цю владу.

Саме в залежності від того на якому рівні відбувається конфлікт потрібно аналізувати можливості використання різних шляхів компромісної взаємодії. У політичних процесах сучасних пострадянських країнах чітко прослідковується боротьба на двох рівнях. Суб'єкти політики без будь якої послідовності намагаються впливати на усі політичні процеси, чим створюють хаос та безлад у політичних 
процесах. На першому рівні сторони намагаються боротися за посади в державних інститутах. Другий рівень розвитку політичних конфліктів розпочинається з початком передвиборчої компанії, коли відбувається передвиборче протиборство різних груп політичних еліт суспільства, протистояння ідеологій та позицій суб'єктів політики, а також вплив на населення через стратегічний вектор подальшого позитивного розвитку суспільства.

Тому, враховуючи усі особливості політичного конфлікту, перш ніж здійснювати певний вплив щодо врегулювання конфлікту необхідно визначити його рівень, мету цього протиборства (зміна влади, піар, популізм, негативний піар для когось із суб'єктів протиборства та ін..), ціль конфлікту та інші фактори, які можуть бути важливі при вирішенні конфлікту.

Адже, під час боротьби за політичну посаду у органах виконавчої влади конфлікт може не набувати публічності та не висвітлюватися в засобах масової інформації, а тому не може бути контрольованим громадянами безпосередньо. Такі конфлікти передбачають зіткнення інтересів окремих політичних лідерів, політичних організацій та груп, які не зацікавлені у публічності їх протиборства. Коли такий конфлікт набуває публічності сторони можуть вдаватися до радикальних засобів, поширювати неправдиву інформацію про опонента, залучати більші кола людей - маси, які можуть вдаватися до сутичок між собою. Така ситуація погано впливає на процес розв'язання протиборства і знайти необхідний шлях досить важко, оскільки сторони конфлікту не будуть надавати повної інформації про причини, цілі та мету такої протистояння.

Не менш важливим завданням є вибір арбітра, так званого медіатора, який неупереджено зможе допомогти сторонам у вирішенні їх протиборства. В такій ролі можуть виступати окремі політики, державні інститути, громадські інститути, міжнародні організації. Пострадянські країни у вирішенні політичних конфліктів досить часто звертаються до авторитетних президентів інших країн, до міжнародних організацій, як урядових так і не урядових, однак не усі сторони конфлікту враховують такий авторитет. Тому важливо, щоб такий суб'єкт-медіатор мав авторитет та вплив на обидві сторони конфлікту.

Для сучасної політичної еліти важливим завданням є розуміння перехідного періоду та процесу демократизації, для того щоб у спірній ситуації сторони змогли домовитись про вирішення цього проти- 
річчя вигідним шляхом для усіх суб'єктів політики, а в першу чергу для громадян. Адже, політики намагаються впливати на громадян, усіма можливими інформаційними шляхами, щоб таким чином обгрунтувати об'єктивність своїх політичних дій та рішень.

Однією з особливостей впливу на громадську думку і завоювання прихильників $є$ проголошення різних цінностей та ідеологічних доктрин, мається на увазі, боротьба концепцій щодо стратегічного розвитку країни у майбутньому. Суб'єкти протиборства дуже активно рекламують свої позиції в мас-медіа у заявах, виступах, промовах публічних діячів, одночасно надаючи факти про хибність концепцій опонентів.

Однією із основних причин боротьби за владу є ідеологічна конкуренція щодо впливу на суспільну думку, що досить ефективно діє у посткомуністичних країнах. Під час зіткнення цінностей і норм суперників сторони вдаються до різних маніпуляцій свідомістю населення та відкрито проголошують систему цінностей і норм суспільного устрою, висвітлюючи громадянам свою позицію, ідеологію.

Оскільки, розбіжності в ідеологіях політичних діячів великі, то і виникають серйозні розбіжності між населенням, що спричиняє зіткнення регіонів, яке небезпечне для цілісності державності.

Звичайно в сучасних новостворених демократичних країнах протиріччя в політичних поглядах неминучі, однак ефективна дипломатія запорука позитивних результатів від політичного конфлікту. Можливість сторін протиборства домовляться свідчить про високий рівень політичної культури та поміркованості суб'єктів політики. У пострадянських країнах відбувається становлення основ політичної культури та політичної свідомості на рівні демократичного політичного режиму. А тому, сучасні політичні конфлікти не завжди мають позитивні результати, а частіше призводять до негативних наслідків для державотворчих процесів і політичної системи загалом. Освідомлення сторонами конфлікту усіх наслідків, а також можливостей непередбаченого негативного результату, має спонукати їх до ефективної взаємодії.

Під непередбаченим негативним результатом, варто розуміти, збройну агресію, яка може бути різною, як зі сторони влади на людей, які невдоволенні політичними рішеннями, так і між окремими групами чи суб'єктами, які визначають межі впливу. У сучасному світі можливості придбати зброю є досить реальні, а шляхи можуть вони бути законні і незаконні, що ще більше ускладнює ситуацію. 
Основне завдання сторін конфлікту - це його розв'язання з максимальним урахуванням інтересів усіх сторін протиборства. Щоб виконати це завдання, сторони повинні володіти високим рівнем культури, який сприятиме швидкому та ефективному способу розв' язання чи управління конфліктною ситуацією.

Під час становлення незалежної правової демократичної держави, суспільство та політичні діячі повинні враховувати, що основним пріоритетом держави є не лише гармонізація національного законодавства до відповідного рівня, а й досягнення гармонізації всередині суспільства, шляхом національної злагоди, гарантування прав людини, культура спілкування між політиками, довіра громадян до політичних діячів, становлення політичної та соціальної стабільності.

Такі основні принципи перетворення суспільства змінюють відношення до політичного протиборства і до політичної боротьби. Населення стане відкрите до удосконалення політичної системи і сприйматиме політичної еліту та зможе довіряти прийнятим рішенням, а вирішення політичних конфліктів не принесе шкоди пересічним громадянам.

Враховуючи ключові вітчизняні завдання та регіональні пріоритети варто пам'ятати, що сучасні політичні конфлікти мають глобальний характер і $є$ закономірним явищем. Конфлікт місцевий чи регіональний може дійти до масштабів міжнародних. Тому в питанні врегулювання і управління конфліктами варто з' ясувати усі передумови, а саме об'єктивні і суб'єктивні обставини, причини конфлікту, його моделювання, визначення декілька варіантів його врегулювання, локалізації, переведення з насильницької форми в ненасильницьку, попередження конфліктної протидії, а не слідування за ним.

При трактуванні дії політичного конфлікту у політичній системі, його впливу на неї, сторони конфлікту здійснюють суб'єктивну характеристику вигідну окремій політичній силі чи політичній еліті. Система характеристики політичних процесів фактично незмінна, а тому суспільні налаштування інколи бувають і песимістичні. Громадяни різної вікової категорії не сприймають прийнятті політичні рішення, не довіряють політикам. Шлях до подолання негативного налаштування це прийняття ефективних, злагоджених політичних рішень, які приносять позитивні результати на шляху до демократизації, а криза політичної думки відступає.

Під час врегулювання політичних конфліктів варто розуміти, яке завдання $є$ перед сторонами протиборства чи потрібно вирішувати 98 
конфлікт, чи ним потрібно ефективно управляти, чи взагалі не реагувати на висловлювання суб'єктів протидії.

У науковій літературі існують різні підходи до розуміння поняття розв'язання політичного конфлікту, але сутність його зводиться до того, що це спільна робота учасників конфлікту з метою закінчити пряму агресію один до одного та вирішити політичне питання, яке стало причиною спору окремих індивідів чи групи осіб.

Для розв'язання політичного конфлікту необхідно, щоб обидві сторони вчиняли дії, щодо вирішення спірного питання, але для цього потрібно дуже багато умов (зрілість сторін, їх зацікавленість у вирішенні спору, підбір методів сторонами чи посередником та ін.). У пострадянських країнах суб'єкти політики часто не усвідомлюють необхідності вирішення конфлікту, не йдуть на поступки і не можуть домовитись між собою, а тому, саме процес розв' язання політичного конфлікту переходить у затяжну політичну кризу, як наслідок страждають від цього прості громадяни, які стають заручниками політичних протиборств на невизнаній частині країни, чи під обстрілами і агресією один до одного.

Вчені вважають, що конфлікт на практиці можливо розв'язати шляхом силового придушення однієї зі сторін чи шляхом переговорів (компроміс, співробітництво, а іноді й поступки). 3 даним твердженням важко погодитись, оскільки, придушення у свойй суті передбачає силовий вплив на одну із сторін з метою завершення конфлікту, але в такому випадку залишиться одна сторона незадоволена, а суть спору не вирішена. Тому такий спосіб розв'язання конфлікту, як придушення, не є ефективний у пострадянських країна, як шлях розв'язання спірної ситуації, адже суперечки за територіальну цілісність чітко показують, що вияв агресії породжує ще більшу агресію.

Придушення ефективне лише в тому випадку, коли група осіб вчиняє вандалізм, пошкоджує адміністративні будівлі, а тим самим порушує норми адміністративного та кримінального законодавства. Але це прояви крайнього впливу сторін протиборства один на одну і є найнебезпечнішою формою політичного конфлікту. Важливо, щоб така форма конфліктної взаємодії не спонукала до радикальних дій.

Такі небезпечні форми політичного конфлікту можуть спонукати треті сили до отримання вигоди з масштабного політичного протистояння. Можливо саме з метою отримання вигоди третя сторона може розпалювати конфліктну протидію між двома суб'єктами по- 
літики, щоб відвести увагу від своєї участі у такому революційному політичному процесі.

Для сучасних України, Молдови і Грузії актуальним є вирішення політичного конфлікту, який призвів до розколу територіальної цілісності, і як наслідок, перебування у невизначеному статусі частини території. Така ситуація негативно впливає на суспільно-політичний розвиток та послаблює економічний потенціал. Вирішення політичного конфлікту, який перейшов у фазу повномасштабних військових дій не можливо шляхом одного дня. Такі конфлікти є затяжними, затратними, неконтрольованими сторонами, оскільки участь приймає велика кількість осіб.

При аналізі військових протистоянь у Молдовії, Грузії і Україні варто розуміти мету протиборства. В Молдовії і Грузії конфлікти подібні, але по відношенню до України дещо інша причина їх виникнення та розвитку. В Придністров'ї та Абхазії мета була отримати незалежність від Молдовії і Грузії відповідно, ще з моменту становлення цих незалежних країн, під час розпаду СРСР. В Україні проблеми зі статусом АР Крим, Луганської і Донецької областей стали причиною внутрішньополітичного військового протистояння уже в 2014 році. Тобто у свідомості населення не було бажання окремої незалежності регіонів до моменту зміни політичної еліти шляхом придушення під час мітингу студентів щодо інтеграційного вектору розвитку країни.

Розпад СРСР зумовив загострення низки конфліктів на пострадянському просторі, зокрема в Абхазіі, Нагірному Карабаху, Придністров'ї, Південній Осетії за сприянням Російської федерації, нажаль не оминула такої участі і Україна.

Слід зазначити, що конфлікт у Молдові хоч і має деякі спільні риси з ситуацією, що склалась в Україні в 2014 році, проте має безліч розбіжностей. Адже сецесіонізм на Донбасі не мав значного поширення і розвитку до 2014 році, а перший його публічний вияв, зумовлений протистоянням регіональної еліти 3 центром отримав своє вираження у 2004 році. На з'їзді лунали заклики до створення нової південно-східної української держави у формі федеративної республіки зі столицею у Харкові. (Казанський, 2014). Варто також зазначити , що 26 листопада 2004 року сесія Луганської обласної ради ухвалила рішення щодо проголошення Автономної ПівденноСхідної Української Республіки та задля реалізації проголошеного рішення звернулася по допомогу до президента Російської федера- 
ції В. Путіна. Проте з огляду на політичне, економічне та соціальне положення тогочасної Росії істотної підтримки сепаратистським проявам регіональної еліти Луганщини, Донеччини та Харківщини північний сусід не надав, але розгорнув масову пропагандистську діяльність на підтримку сецесійних рухів в Україні.

Крім того представники Луганської та Донецької області прийняли рішення про проведення референдуму, запланованого на грудень 2004 року стосовно їх самостійності у межах «української федерації» та заявили про відмову перерахування грошей до державного бюджету і про свою юрисдикцію над міліцією да інших державних органів, що розташовані в межах даних областей. Готовність до аналогічні дії напередодні заявило керівництво Харківської області.

Після завершення виборчої епопеї 2004 року належних висновків, щодо подолання зародженого сепаратизму влада не зробила, до відповідальності за антидержавні дії направлені на повалення державного ладу нікого з учасників сумнозвісних подій не притягнули. Адже відповідно до статті 109 Кримінального кодексу України дії, вчинені з метою насильницької зміни чи повалення конституційного ладу або захоплення державної влади, а також змова про вчинення таких дій - караються позбавленням волі на строк від п'яти до десяти років. А також публічні заклики до насильницької зміни чи повалення конституційного ладу або до захоплення державної влади, а також розповсюдження матеріалів із закликами до вчинення таких дій - караються обмеженням волі на строк до трьох років або позбавленням волі на той же строк. Крім того дії, публічні заклики до зміни конституційного ладу в позазаконний спосіб вчинені особою, яка є представником влади з використанням засобів масової інформації,караються обмеженням волі на строк до п'яти років або позбавленням волі на той же строк (Кримінальний кодекс України, 2001).

Поняття конституційного ладу включає суверенітет України, іiі форму правління, територіальний устрій та політичний режим. У зв'язку з цим рішення учасників сєверодонецького зібрання та Луганської, Донецької і Харківської обласних рад слід розцінювати як дії направлені на зміну територіального устрою держави незаконним способом. Але ці дії залишились без належних санкцій та склали негативний прецедент, що у майбутньому призвів до реальної втрати контролю Україною над окремими своїми територіями.

А от у Придністров'ї, Абхазії та Південній Осетії прагнення до відокремлення від держави та подальше приєднання до Російської 
федерації проявились під час розпаду СРСР. Конфлікти, що виникли у Молдові та Грузії зумовлені передусім діаметрально протилежним баченням подальшого розвитку новостворених держав у їх окремих регіонах. Так орієнтована на Європу та Румунію еліта Республіки Молдова зіштовхнулась 3 проросійськоорієнтованою регіональною елітою Придністров'я, яка отримала всебічну підтримку Росії. Аналогічний процес відбувався у взаємодії Грузії і іï регіонів Абхазії та Південної Осетії. Зокрема контроль Тбілісі над Абхазькою автономією був втрачений за самого початку проголошення незалежності Грузії.

Зумовлені ці конфлікти були історичними, геополітичними, економічними та культурними чинниками, а сторони конфлікту розраховували на зовнішню підтримку. У випадку з Придністров' ям Тирасполь залучився підтримкою Російської федерації, а офіційний Кишинів розраховував на підтримку Румунії. Крім того значною складовою сецесії у всіх випадках, що розглядаються у дослідженні, мала інформаційна складова, тобто пропаганда, що розгорнулась у контрольованих Російською федерацією 3МI.

Саме готовність підтримки Росії сепаратистських настроїв у Придністров'ї, Південній Осетії та Україні зумовили їх радикалізацію, а отже перехід конфліктів із латентної стадії у пряме військове зіткнення.

Безумовно, що оптимізму придністровським сепаратистам надавала упевненість у тому, що їх регіон є локомотивом економічного розвитку Молдови. Зокрема у Придністров'ї станом на 1992 рік було сконцентрована значна частина промислових потужностей Молдови, у той час коли решта території держави залишалася аграрною. Отож придністровська еліта переконуючи населення у економічній самостійності регіону взяла курс на сецесію.

Аналогічні настрої домінували серед населення Донецької та Луганської областей України, що підбурені своїми регіональними елітами прагнули відокремлення від України в 2014 році і чи не найважливіший вплив на настрої мас здійснювали засоби масової інформації Російської федерації, що створювали образ ворога для населення як Придністров'я так і українського сходу в особі політичної еліти Молдови та України і їх геополітичної орієнтації. Дані 3МІ активно використовувались для розпалювання регіональних конфліктів в Україні та Молдові, використовуючи негативні епітети та порівняння на адресу як заходу України так і Молдови. Апелюючи добре сформованими міфологемами історичної пам'яті у населення 
їм вдалося закріпити ідеологічне протистояння окремих регіонів Молдови та України, що спровокувало військове протистояння у суспільстві зазначених держав.

Отож через особливості геополітичного розташування придністровський регіон є полем боротьби за сфери впливу. Вагому роль тут відіграє Росія, яка сприймає Придністров'я як архетип «русского мира» та інструмент протидії просуванню НАТО у південносхідному напрямку Європейського регіону (Мандрагеля, 2003, с. 405). Росія розглядає зближення Молдови і України з Європейським союзом та НАТО як процес, що загрожує геополітичним інтересам, а отже національній безпеці. Усвідомлюючи зовнішньополітичні інтереси Російської федерації та подальший процес євроінтеграції Молдови, а також прагнення окремих політичних партій республіки до інтеграції з Румунією можна припустити, що статус-кво, який зберігається понад двадцять років в придністровському конфлікті може бути порушено.

Слід зазначити, що найбільш значущою рисою сецесіоністських рухів є сукупність ідеологічних чинників, зокрема історична пам'ять, мова, політичні погляди, етнічність, що інтегрують сецесіоністів і протиставляють їх державі.

3 огляду на особливість прояву сецесіонізму у Придністровї та ЛНР і ДНР їх слід віднести до іредентизму. Під яким варто розуміти прагнення окремої частини населення держави до територіального відокремлення від центру з метою приєднання до іншої держави, що за переконанням сепаратисько налаштованого населення $є$ історичною, культурною, етнічною спільністтю з ними. Саме тривале перебування Молдови, Грузії та України у спільному з Росією інформаційному просторі, а також спільність певного історичного шляху спровокувало у частини населення формування так званої російської, або, точніше сказати, радянської ідентичності та сприйняття себе як спільного політико-культурного, історичного, мовного простору в якому Росія є об'єднуючим стрижнем. Не даремно теоретики «русского миру» продовжують імперсько-радянську ідеологему про єдність «братських народів», що базується на спільності історії, православ'я та мови. Дана концепція це прагнення російської політичної та церковної еліти до відродження імперії в територіальних межах колишнього СРСР.

Проте варто зазначити, що сецесія у Абхазії та Південній Осетії була зумовлена етнічною самоідентичністю місцевого населення, 
що в пізньому періоді існування СРСР, а в Придністров'ї чинником сепаратизму була радянська ідентичність населення даного регіону, що не визнавало курсу Молдови на інтеграцію Молдови з Румунією та частково етнічна російська ідентичність лівобережжя Дністра. Натомість іредентизм на сході України формувався поступово в межах технології впровадження так званого «русского мира».

Концепція «русского мира» почала формуватися у Російській федерації як ідеологія, що мусила замінити радянську міфологему єдності братських народів, аби подолати ефект роздробленості народу, який виник після розпаду радянської держави. Основними засадами цієї ідеології є спільність російської мови, православної віри та ідентифікації себе з Росією, іії культурно-історичною спадщиною. Аоткуляторами даної концепції сьогодні є президент Російської федерації В. Путін та патріарх Російської православної церкви Кирил.

«Русский мир» розглядається авторами цієї концепції як культурно-історична єдність у межах так званої руської цивілізації, що об'єднує усіх «співвітчизників» Росії, які входять в їі мовний, ідеологічний простір і складають так звану руську цивілізацію. Виходячи 3 промов настоятеля Російської православної церкви «русский мир» це єднання усіх православних народів і тих що розділяють основні цінності цієї цивілізації, ядром якої є Росія, Україна та Білорусія (Волкова, 2016).

Саме завдяки діяльності різних проросійських громадських організацій, переважно на південному-сході України та російським засобам масової інформації, а також лояльним до російської пропаганди українським 3МІ населення південно-східної частини нашої держави було втягнуте у поле «русского мира», що з рештою сприяло їх прагненню до відокремлення від України та єднанню з Росією, як матричною державою. Варто зазначити, що українська держава протягом усього періоду незалежності не створила дієвого механізму інтеграції регіонів та налагодження спільного комунікативного поля.

До того ж загострення партійної боротьби в середині держави лише сприяло подальшому регіональному розколу в Україні. Український регіоналізм здебільшого спровокований електоральною політикою та політичними гаслами багатьох партій. Адже найпростішою формулою накопичення «електорального капіталу» $є$ гра на регіональних, культурних, мовних, конфесійних відмінностях між окремими частинами держави, направлена на конфронтацію електорату різних регіонів. 
Партійна система України останнє десятиліття характеризувалася двовекторною спрямованістю партій у, якій частина партій активно агітувала електорат за приєднання до Митного союзу та апелювала до ідеї спільності Росії, Білорусії, України та активно грала на ностальгії за радянськими часами їх цінностями та ідеалами. Решта політичних партій орієнтувалася у своїй агітації на європейський вибір подальшого майбутнього України ії традиційні цінності та історичне минуле (Кройтор, 2018, с. 60-63).

Така дихотомія партійної системи зберігається наразі з однією лише відмінністю, що партії умовно можна розділити на прихильників євроінтеграції, інтеграції з НАТО та прихильників пошуку компромісу з Російською федерацією. Не важко зрозуміти, що така поляризація партій призвела до розколу електорату, що зрештою зумовило загострення конфлікту між регіонами держави, ії елітами та лише сприяло сецесії східних областей України (проголошення «ДНР» та «ЛНР»), чим скористувалась Російська федерація, а ідея «русского мира» стала ідеологічним оформленням сепаратизму.

Дещо подібною є ситуація з партійною системою Республіки Молдова. 3 погляду ідеологічного спектру то політичні партії Молдови можна поділити на партії орієнтовані на європейську інтеграцію та про-російські політичні партії. Зокрема праві політичні партії репрезентовані уніоністськими партіями, які виступають за приєднання Молдови до Румунії, сприймаючи незалежність республіки як перехідний етап інтеграції з «Великою Румунією», ліві партії представлені партіями проросійського налаштування, що виступають за нове об'єднання з СНД. Центристські політичні партії відстоюють збереження незалежність Молдови.

Стосовно партійної палітри Грузії, варто зазначити, що їй не притаманна така поляризація у поглядах на зовнішньополітичний курс, що характерно Україні та Молдові. Так за словами О. Панфілова «грузинське суспільство налаштоване ще з референдуму січня 2008 року на інтеграцію з СС і НАТО. Більше 70 відсотків населення сказало, що хоче інтеграції з Євросоюзом і 60 відсотків за інтеграцію з НАТО. Думки не змінювалися. Але грузинські політики вважають, що нам зараз інтеграція з НАТО значно важливіша за інтеграцію з Євросоюзом. НАТО - це безпека. У Грузії є навчальний центр НАТО, який називають «базою» НАТО. Декілька разів на рік проходять навчання на території Грузії (Куриленко, 2018). 
Однак правляча еліта Грузії проводить щодо Російської Федерації «політику стратегічного терпіння», що грунтується на подальшій співпраці двох держав в межах Женевських домовленостей та поглибленню торгівельної співпраці. Так Росія у межах торгівельноекономічних відносинах з Грузією поступається лише Туреччині. Проте подальша залежність Грузії від російського ринку лише посилить ії залежність від північного сусіда, у той же час все більше Абхазія та Південна Осетія інтегруються в економічний простір Росії. Проте відмінність цих двох регіонів Грузії від «ЛНР» та «ДНР» в тому, що їх важко віднести до «русского мира» і навряд чи населення цих регіонів ідентифікує себе з цим світом.

Сецесія цих регіонів Грузії, на відміну від Придністров'я в Молдові, Луганської, Донецької області в Україні, не є іредентизмом, а має всі ознаки індепендизму. Як зазначає В. Ставрійчук «сецесіонізм - це політика і практика суспільнополітичного руху, що спрямовані на здобуття державного суверенітету окремою етносоціальною спільнотою на території ії проживання в межах існуючої держави (індепендизм) або прагнення до об'єднання частин одного етносу, що мешкають у різних державах (іредентизм)».

Крім того конфлікти Абхазії та Південної Осетії у Грузії, мають етнічну та історичну зумовленість, і розгорілись як міжетнічний конфлікт осетинсько-грузинський та абхазько-грузинський, який у подальшому Російська федерація використала в своїх геополітичних інтересах, враховуючи прагнення Грузії до асоціації з СС та інтеграції з НАТО. У цьому контексті спільність конфліктів у Молдові, Грузії, та Україні полягає у діях Російської Федерації пов'язаних з введенням своїх військ на територію суверенних держав у період коли вони змінили вектор своєї зовнішньої політики на інтеграцію до європейського простору.

На відміну від Придністров'я, Абхазії і Осетії, «ЛНР», «ДНР» розглядались Росією як територія для подальшого наступу на Україну, з огляду на спроби реалізації проекту «Новоросія» та публічні висловлювання правлячої еліти Російської федерації, щодо України.

Усі конфлікти пов' язані з сецесіонізмом, що розглядаються мають низку спільних аспектів. Передусім це присутність у них військових сил Російської федерації та активна пропагандистська діяльність направлена на підтримку розколу держав. Фактично розгорнута Росією «гібридна війна» проти Республіки Молдова в 1992, була апробована 106 
в Грузії у 2004 році та удосконалюється на сучасному етапі у боротьбі проти України.

Варто погодитись із О. Снігир, яка зазначає, що «Україна, Молдова і Грузія були об'єктами російської агресії з моменту розпаду СРСР. Прояви російського втручання, його інструменти і засоби в усіх трьох країнах були схожі й відрізнялися лише з огляду на регіональну специфіку та рівень стійкості країн до зовнішнього впливу. Запізніла російська воєнна агресія проти України зумовлена тим, що Україна розглядалася як один зі стовпів майбутньої інтеграції у форматі СНД. Кремль на початку 1990-х задовольнився дислокацією військовоморської бази в Криму і розраховував на лояльність української політичної еліти. Саме тому конфлікт з Росією та анексія Криму стали відкладеними в часі, однак невідворотними з огляду на недієвість інших інструментів Кремля для утримання контролю над Україною» (Снігир, 2018).

Дослідниця вбачає причину відтермінування російської агресії проти України в тому, що політична еліта цієї держави розраховувала на подальшу можливість інтеграції України з СНД та Митним союзом, а також на лояльність вітчизняної еліти до Російської федерації. На таку лояльність не можна було розраховувати у відносинах з Кишинівом. Тому завдяки пропаганді у 3MI, направленої на залякування жителів Придністров' я жорсткою політикою румунізацією місцевого населення, що має намір розгорнути правлячі кола Молдови. Це зумовило виступи придністровської регіональної еліти проти Кишинева, а Росії задіяти свої військові формування, які базувались у даному регіоні на підтримку сепаратиського руху.

Аналогічні дії вжила Російська федерація по відношенню до Південної Осетії граючи на національних протиріччях осетинців та грузинів, сформувавши у ЗМІ образ ворога офіційного Тбілісі, що проводить жорстку грузинську національну політику, яка становить загрозу існуванню осетинській спільноті. Присутність російського військового контингенту на території Грузії лише полегшало інтервенції Росії в Південній Осетії. І в першому і в другому випадку Російська федерація виправдовувала свою військову присутність у цих двох державах ідеєю «примусу до миру».

Другий чинник який об'єднує конфлікти в Молдові, Грузії та Україні є те що каталізатором конфлікту у Придністров'ї, Південній Осетії і Донбасі стало обрання Кишеневом інтеграції з Румунією та ЄС, а Києвом і Тбілісі євроінтеграції та зближення з НАТО. Крім того 
значним чинником конфлікту у Молдові та Україні стала політика щодо державної мови та історичної пам'яті, яку російські та лояльні до них молдавські та українські 3МІ трактували як ухили до «фашизму», що підігрівало відцентрові тенденції периферії.

Окупація Криму Російська федерація виправдовувала захистом російськомовного населення від київської «хунти», яка внаслідок перевороту захопила владу в Україні. Таке ідеологічне виправдання агресії проти держав колишнього СРСР сформоване в концепції «русского мира», як захист «соотечетвиников» не є новим, адже сформоване ще в середовищі імперського періоду.

Прикладом такої ідеології є Маніфест головнокомандувача російської армії великого князя Миколи Миколайовича від 18 серпня 1914 р. «Русскому народу». Зокрема у документі проголошувалось: «Да не будет больше подъярмленной Руси! Достояние Владимира Святого, земля Ярослава Осмомысла и князей Даниила и Романа, сбросив иго, да водрузит стяг единой, неразделимой и великой Росии! Да свершится Промысел Божий, благословивший дело великих собирателей земли Русской. Да поможет Господь царственному своему помазаннику, императору Николаю Александровичу всея России, завершить дела великого князя Ивана Калиты». Ось таким «собирательством» земель «Святої Русі» виправдовувались дії Російської імперії в 1914 році у Першій світовій війні (Дорошенко, 2002, с. 31).

У роки Другої світової війни СРСР, аналогічно виправдовує своє агресію проти Польщі, але з маленькою поправкою, щодо об єднання братського народу українців, що живуть у Галичині. Аналогія простежується стосовно дій Російської федерації у Придністров'ї, Криму, Донецьку.

Третьою спільною ознакою є перебіг конфлікту, наявність паралельно $з$ військовими діями переговорного процесу з метою врегулювання конфлікту з залученням Європейських держав та Російської федерації. У жодному з конфліктів Росія не визнає себе стороною конфлікту, а стосовно Донбасу вона не визнає навіть присутності своїх війсь на території України, наполягаючи на своїй місії як посередника. О Снігир зазначає, що «позиція посередника в конфліктах, яку займала або намагається зайняти Росія, дозволяє їй повністю контролювати безкінечний переговорний процес із врегулювання конфліктів, не беручи на себе жодних зобов' язань. А оскільки Москва не була зацікавлена в політичному врегулюванні конфліктів, то ані 108 
ПМР, ані Абхазія з Південною Осетією, ані «ДНР» і «ЛНР» не готові були домовлятися з Кишиневом, Тбілісі та Києвом» (Снігир, 2018).

Варто зазначити що Молдова визнала «ПМР» стороною у конфлікті та розпочала діалог по врегулюванню конфлікту у форматі Молдова - Тирасполь при посередництві Росії, України та ОБСС. У цьому форматі ЄС та США є спостерігачами. Переговорний процес щодо врегулювання абхазького конфлікту проходив під егідою ООН при посередництві Росії і суб'єктності Абхазії та Грузії. Переговори щодо врегулювання південно-осетинського конфлікту проходили у Женевському форматі, проте Російська федерація була визнана Грузією суб'єктом конфлікту поруч із південною Осетією. Проте квола міжнародна реакція на агресивні дії російської сторони не сприяли належному врегулюванню конфлікту і спровокували подальший розкол території Грузії. Адже російська федерація визнала незалежність не лише Абхазії, але й Південної Осетії.

Якісною відмінністю переговорного процесу, щодо врегулювання військового конфлікту на сході України є те, що в межах Мінського переговорного процесу Україна не визнає стороною переговорів ні «ЛНР» ні «ДНР», визнаючи стороною конфлікту Російську федерацію. Посередниками у переговорах є Німеччина та Франція. Крім того врегулювання конфлікту відбувається в межах «норманської четвірки» - Україна-Франція-Німеччина-Росія.

Четвертою спільною ознакою є пропозиції урядів Молдови, Грузії та України після деескалації конфліктів надати відповідним територіям широких самоврядних прав. Проте Російська федерація наполягає на проекті федералізації держави, який Україна відкидає як не прийнятний та такий, що в подальшому загрожує існуванню державності.

Ще одною схожістю між «ПМР», Південною Осетією та «ЛНР» і «ДНР» $є$ тещо всі вони є не визнані світовим співтовариством держави та мають пряму фінансово-політичну підтримку збоку Російської федерації. Проте деякі відмінності є, а саме за протекцією Росії Абхазію та Південну Осетію визнали Венесуела, Вануату, Нікарагуа, Сирія, Тувалу і Російська федерація, а от Придністровська Молдавська Республіка залишається не визнаною ні ким так само як і не визнаними залишаються «ДНР» та «ЛНР».

Отож, участь Росії у придністровському, абхазькому, південноосетинському та сході України слід розцінювати як прагнення до контролю над даними територіями, з подальшим їх приєднанням 
до своєї території на що вказують процеси інтеграції в економічний, політичний та культурний простір Російської федерація не визнаних, самопроголошених республік.

Залишається відкритим питанням чи зазнає «русский мир» свого територіального розширення завдяки методам «гібридної війни» проти інших пострадянських держав? Єдиним спільним суб'єктом в цих військових політичних конфліктах в усіх трьох пострадянських країнах $є$ третя сила, яка не вважає себе стороною конфлікту, але приймає активну участь у їх розвитку. Такою третьою силою $є$ керівництво та військові формування Російської Федерації, які активно приймають участь у військових протиборствах. Така третя сила $є$ маніпулятором, а громадяни та території окупації є фактичними iї заручниками, хоча не усі мешканці цих територій мають таке бачення. У зв'язку з розвитком сучасних військових протиборств на свідомість населення активно впливають інформаційні потоки потрібного напрямку, усі інші види інформації намагаються обмежити будь-яким чином.

Для Грузії та Молдови фаза відкритого військового протистояння зупинена, але конфлікт залишається не вирішеним. Спірна територія знаходиться під невизначеним статусом в геополітичному просторі та в глибокому економічному занепаді. В Україні конфлікт знаходиться в активній фазі і механізм завершення хоча б військової агресії не відпрацьований, що продовжує спричиняти значні шкоди для життя i здоров'я населення, приводить в непридатність території військового протистояння та обмежувати економічний розвиток держави.

Для України першочерговим завданням є встановлення так званого «холодного миру», який допоможе завершити стадію військової агресії, звільнити окуповані території та розпочати відновлення правової стабільності і відновлення економічного потенціалу. Україна не бажає вдаватися до радикальних заходів, вводити військовий стан та звільняти окуповані території (як це зробила Молдавія), а тому завершення військової стадії не можливо спрогнозувати. Статус військового протиборства нормативно регламентується різними назвами: перша антитерористична операція на сході України (АТО), друга Операція об'єднаних сил (ООС), однак зміна назви ніяк не впливає на фактичні обставини протиборства, які там розвиваються. Фактично з обох сторін відбуваються військові атаки професійними військовими з метою звільнити чи окупувати більшу територію. 
Отже, придушення в різних формах свого прояву є спланованою дією направленою на створення хаосу, безладу, безвладдя, або засобом відведення від основного суб'єкта, який зацікавлений у владі і владних силах. Закінчення конфлікту, яке йде за придушенням - це втрата однієї із складових політичного конфлікту, якщо втрата була жертовною, вона 3 часом проявиться 3 новою силою, можливо в іншому складі конфлікту, але вирішити такий конфлікт буде дуже важко.

Адже, в сучасних процесах жорсткої агресії на теренах посттоталітарних країн під час політичного протиборства використовується тотальна війна, суть їі в тому, що вплив на сторону, яку намагаються «придушити», здійснюється з усіх можливих шляхів, а саме: інформаційним шляхом, адміністративним ресурсом, людською силою та ін.. Це прояв сучасного механізму впливу на суб'єкти протиборства, атака з усіх можливих сторін.

Тому, в сучасному геополітичному просторі, у який входять пострадянські країни, основна увага при вирішенні конфлікту приділяється саме компромісним і консенсусним шляхам врегулювання протиборства. При розв' язанні конфліктів саме таким чином, проблема виникає в самій політичній еліті і в свідомості населення, яке демократичним шляхом обирає цю еліту.

Усі вчинки, які здійснюються правлячою владою мають містити елементи раціональності під час вирішення політичного конфлікту. Оскільки, сторони рівні у своїх бажаннях, мають бути рівні у способі впливу один на одного, без використання адміністративного ресурсу 3 метою задовольнити інтереси однієї із сторін. У зв'язку з інформаційним прогресом сучасні суб'єкти протиборства мають великі можливості отримати інформацію щодо застосування адміністративного ресурсу, масштаби використання адміністративного ресурсу та наслідки такого впливу. Всі способи використання «радянських методик впливу» стають застарілими у сучасному політичному процесі, а політичні діячі часто програють у протиборстві з окремими зацікавленими групами осіб, і відбуваються радикальні зміни у політичній системі.

Під час розв' язання сучасного політичного конфлікту у пострадянських країнах ключовою умовою для сторін конфлікту є визнання сторонами факту протиборства один з одним. Якщо одна із сторін не визнає себе стороною конфлікту, відносить себе до числа посередників, то в такому випадку вирішити конфлікт не можливо. При таких обставинах між цими сторонами врегулювання політичного 
конфлікту не можливе, політична криза буде продовжуватися до зміни політичної еліти та суб'єктів влади.

Отже, для повного розв'язання військового конфлікту в Україні, Молдовії і Грузії необхідно, щоб змінилася правляча еліта в третій силі, а саме в Російській Федерації. За таких обставин влада в країні і регіональна еліта на конфліктній території зможуть самостійно здійснювати переговорний процес і вирішувати статусні особливості територій, їх виокремлення чи об'єднання, але в межах правового поля країни, до якої відносяться данні території в рамках міжнародного права. А правляча еліта Російської Федерації не буде здійснювати вплив на фактичні сторони, не буде надавати військову підтримку та матеріальну допомогу.

Оскільки, військовий конфлікт не можливо розв'язати одним із дієвих механізмів, варто здійснювати заходи управління процесами протиборства, з метою зменшення агресії сторін одна до одної, i захисту мирного населення від наслідків протиборства.

Відносно трактування поняття «управління політичним конфліктом», то в науковому обігу його тлумачать, як ціленаправлений вплив на корекцію поведінки учасників конфлікту.

Здійснювати такий вплив необхідно з метою обмеження в небезпечних діях, які негативно впливають на усіх громадян. У пострадянських країнах управляти ефективно конфліктами досить важко, тим більше коли конфлікт військовий. Лише 3 метою отримання вигоди сторони змінюють модель своєї поведінки, але це не довгострокові акції і вони не спонукають сторони до розв' язаня конфлікту у майбутньому.

У військовому конфлікті важливими моментами, щодо управління протиборством $є$ такі дії, як: обмін полоненими, домовленість про перемир'я на відповідний період, гарантування надання населенню гуманітарної допомоги у побутових речах та продуктах харчування, території проживання яких постраждали.

Управління конфліктом в рамках військового протиборства не вирішує його причини, але відводить сторони від радикальних заходів та сприяє, на майбутнє, створення превентивних заходів до прямої агресії. В рамках України усі переговори щодо управління військовими процесами вирішуються частково. Переговори про обмін полоненими чи про оголошення миру зриваються, сторони стають більш агресивними один до одного. В Молдавії та Грузії рішення про зупинення військових дій фактично виконується, але таке замороження конфлікту досить небезпечне. 
Враховуючи усе вищезазначене, порівняльний аналіз трьох пострадянських країн показує, що країни стикаються в своєму розвитку 3 подібними політико-територіальними конфліктами, політична еліта суспільства досить розшарована та різновекторна, що унеможливлює вирішення конфліктного зіткнення та послаблює стабільність усієї країни загалом, а пізніше і всього регіону.

Грузія $є$ найбільш успішною з країн, які проходять порівняння, однак в силу власних ментальних особливостей та впливу третьої сторони вже довгий період часу знаходиться в стані замороженого військового конфлікту.

Молдавія практично законсервувала конфлікт на невизначений період, а перебування на території держави іноземних військ фактично стала нормою їх функціонування.

Україна залишається в стані активних військових дій, ситуація залишається досить напруженою, але в силу того, що конфлікт став затяжним для українського суспільства військові агресія стала причиною переосмислення політичних процесів за усі роки незалежності.

Розв' язання територіальних конфліктів у політичній площині цих країн потребує дипломатичного підходу і бажання представниками сторін до мирного закінчення протидії. На сучасному етапі повноцінно вирішити данні конфлікти переговорним шляхом не можливо. Важливо, щоб сторони свідомо бажали розв' язання конфлікту та запропонували механізми вирішення, які задовольнять обидві сторони. Тому, більшу увагу варто приділити управлінню конфліктами для зменшення або взагалі обмеження агресії. Під час відшукання поодиноких шляхів взаємодії суб'єкти конфлікту з часом прийдуть до необхідності правового визначення усіх політичних та економічних дій. А міжнародна спільнота прийме будь-яке геополітичне рішення, якщо воно буде в рамках правового поля та дасть гарантії миру та стабільності, яка впливає не лише на окремі країни а й на міжнародну політику загалом.

\section{Лimepamypa:}

Волкова, Є. (2016). Ідеологія «русского мира» як релігія війни. Zbruc. URL: https://zbruc.eu/node/51719.

Дорошенко, Д. (2002). Маніфест головного команданта російської армії великого князя Миколи Миколайовича від 18 серпня 1914 р. «Русскому народу». Історія Украӥни. Київ: Темпора.

Завгородня, Ю. (2018). Політичний конфлікт в умовах транзитного суспільства. Правові та інституиійні механізми забезпечення розвитку 
України в умовах європейської інтеграції: матеріали Міжнародної науковопрактичної конферениї (м. Одеса, 18 травня 2018 р.) У 2-х т. Т. 1 / відп. ред. Г. О. Ульянова. Одеса: Видавничий дім «Гельветика», 225-227.

Казанський, Д. (2014). Сєвєродонецькі роковини. Тиждень иа. URL: https:/ / tyzhden.ua/Politics/123996.

Кримінальний кодекс України від 05.04.2001 р. № 2341-III (Верховна Рада України). Офічійний сайт Верховної Ради України URL: https:/ / zakon. rada.gov.ua/laws/show/2341-14.

Кройтор, А. (2018). Партійні системи України та Республіки Молдова: порівняльний аналіз. Транскордонне співробітництво: перспективи, проблеми, рішення: збірник наукових праць Міжнародної науковопрактичної конференції «Транскордонне співробітництво: перспективи, проблеми, рішення». Одеса, 60-63.

Куриленко, О. (2018). Кавказький «русскій мір» відрізняється від України - відомий письменник. Олег Панфілов розповів про політичну кухню в Грузії. Апостоф. URL: https://apostrophe.ua/ ua/article/politics / foreign-policy/2018-10-30/kavkazskiy-russkiy-mirotlichaetsya-ot-ukrainyi---izvestnyiy-pisatel/21691.

Мандрагеля, В. А. (2003). Причини та характер воєн (збройних конфліктів): філософсько-соціологічний аналіз. Київ: Нац. акад. оборони України, Ін-т вищої освіти АПН України.

Снігир, О. (2018). Російський експансіонізм у Молдові, Грузії та Україні: паралелі й відмінності. Зеркало тижня. URL: https://dt.ua/ international/rosiyskiy-ekspansionizm-u-moldovi-gruziyi-ta-ukrayiniparaleli-y-vidminnosti-278236_.html.

\section{References:}

Volkova, Ye. (2016). Ideologiya «russkogo my`ra» yak religiya vijny` [The ideology of the "Russian world" as a religion of war]. Zbruc [Zbruc]. URL: https://zbruc.eu/node/51719. [in Ukrainian].

Doroshenko, D. (2002). Manifest golovnogo komandanta rosijs koyi armiyi vely `kogo knyazya My koly`My kolajovy cha vid 18 serpnya 1914 r. «Russkomu narodu». Istoriya Ukrayiny [Manifesto of the Commander-in-Chief of the Russian Army of Grand Duke Nikolai Nikolaevich of August 18, 1914 to the Russian People. History of Ukraine]. Kyiv: Tempora. [in Ukrainian]. Zavgorodnya, Yu. (2018). Polity`chny`j konflikt v umovax tranzy`tnogo suspil`stva [Political conflict in the context of a transit society]. Pravovi 
ta insty 'tucijni mexanizmy' zabezpechennya rozvy'tku Ukrayiny' $v$ umovax yevropejs 'koyi integraciyi: materialy` Mizhnarodnoyi naukovo-prakty`chnoyi konferenciyi (m. Odesa, 18 travnya 2018 r.) U 2-x t. T. 1 / vidp. red. G. O. Ul yanova [Legal and Institutional Mechanisms for Ensuring Ukraine's Development in the Conditions of European Integration: Proceedings of the International Scientific and Practical Conference (Odesa, May 18, 2018) In 2 vols. ed. G. O. Ulyanov]. Odesa: Vy`davny`chy`j dim «Gel`vety`ka», 225-227. [in Ukrainian].

Kazans`ky`j, D. (2014). Syevyerodonecz`ki rokovy`ny` [Severodonetsk Anniversary]. Ty zhden 'ua [Week ua.]. URL: https://tyzhden.ua/ Politics/123996. [in Ukrainian].

Kry 'minal ny j kodeks Ukrayiny vid 05.04.2001 r. \# 2341-III [Criminal Code of Ukraine dated 05.04.2001 № 2341-III] (Verxovna Rada Ukrayiny`). Oficijny ’j sajt Verxounoyi Rady' Ukrayiny [Official site of the Verkhovna Rada of Ukraine]. URL: https:/ / zakon.rada.gov.ua/laws/show/2341-14. [in Ukrainian].

Krojtor, A. (2018). Partijni sy`stemy` Ukrayiny` ta Respubliky`Moldova: porivnyal`ny $\mathrm{j}$ analiz [Party systems of Ukraine and Republic of Moldova: comparative analysis]. Transkordonne spivrobitny 'cztvo: perspekty 'vy', problemy`, rishennya: zbirny`k naukovy`x pracz`Mizhnarodnoyi naukovo-prakty`chnoyi konferenciyi «Transkordonne spivrobitny`cztvo: perspekty`vy`, problemy`, rishennya» [Cross-border cooperation: perspectives, problems, solutions: collection of scientific papers of the International scientific-practical conference "Cross-border cooperation: perspectives, problems, solutions"]. Odesa, 60-63. [in Ukrainian].

Kury`lenko, O. (2018). Kavkaz`ky`j «russkij mir» vidriznyayet`sya vid Ukrayiny` - vidomy`j py`s`menny`k. Oleg Panfilov rozpoviv pro polity`chnu kuxnyu v Gruziyi [The Caucasian "Russian measure" differs from Ukraine - the famous writer. Oleg Panfilov spoke about political cuisine in Georgia]. Apostof [Apostrophe]. URL: https:/ /apostrophe.ua/ ua/article/politics/foreign-policy/2018-10-30/kavkazskiy-russkiy-mirotlichaetsya-ot-ukrainyi---izvestnyiy-pisatel/21691. [in Ukrainian].

Mandragelya, V. A. (2003). Pry'chy 'ny ta xarakter voyen (zbrojny'x konfliktiv): filosofs 'ko-sociologichny j analiz [Causes and nature of wars (armed conflicts): philosophical and sociological analysis]. Kyiv: Nacz. akad. oborony Ukrayiny`, In-t vy`shhoyi osvity`APN Ukrayiny`. [in Ukrainian].

Snigy`r, O. (2018). Rosijs`ky`j ekspansionizm u Moldovi, Gruziyi ta Ukrayini: paraleli j vidminnosti [Russian Expansionism in Moldova, 
Georgia and Ukraine: Parallels and Differences]. Zerkalo ty zhnya [The mirror of the week]. URL: https://dt.ua/international/rosiyskiyekspansionizm-u-moldovi-gruziyi-ta-ukrayini-paraleli-y-vidminnosti278236_html. [in Ukrainian].

\section{Анотація}

Завгородня Ю.В., Кройтор А.В., Пехник А.В. Особливості розВ'язання конфліктів та управління конфліктами у пострадянських крайнах (на прикладі Молдови, Грузї, України). - Стаття.

Політичний конфлікт містить загальні ознаки, які виділяють його від інших суспільних конфліктів, а можливі шляхи розвитку і подолання конфліктної ситуації уже встановленні на теоретичному та практичному рівнях. Однак, сучасна історія пострадянських країн свідчить про небезпеку політичних конфлліктів, оскільки сторони протиборства не завжди використовують загальноприйняті правила дипломатичного врегулювання конфліктів, а тому відбувається консервування конфліктних протиріч на невизначений період.

Особливості ескалачіï протиборства на теренах Молдови, Грузії та Украйни демонструють небезпечні наслідки військових конфліктів, які виникли на підставі розвитку політичних процесів, а тому потребують уваги та детального аналізу. Сторони вдаються до непередбачуваних діӣ, а усі відомі шляхи врегулювання конфліктів не приводять до вирішення конфліктів.

Звичайно, пострадянські країни на конфліктологічній мапі демонструють специфічні шляхи розвитку політичного конфлікту, його ескалацї та особливості призупинення. Вирішення конфліктної ситуації у пострадянських краӥнах часто спонукає сторони до подальшого $і$ сильнішого загострення. Суб'єкти політичного конфлікту доходять до критичної точки протиборства, а саме збройного протистояння.

У період Радянського союзу конфлікти взагалі не вирішувалися, вони публічно не розголошувалися і наукового дослідження, щуодо даного питання, практично не існувало. 3 становленням незалежних пострадянських держав політичний конфлікт став проявлятися в різних сорерах суспільного життя публічно, що сприяло науковій активності В конфліктному напрямку дослідження. Тому, особливості щодо врегулювання політичного конфлікту розпочинають висвітлювати в період становлення незалежних пострадянських держав.

Уже встановлений науковий факт, щзо посткомуністичні країни складно переходять до демократії та по різному сприймають цей процес, оскільки, 116 
одні законсервувались на невизначений термін, інші швидко перелаштувались на новий лад, треті ніяк не можуть визначитись з вектором розвитку. Цей процес науковиями трактується, як непослідовний, суперечливий та необачний.

Ключові слова: політичний конфлікт, дипломатія, переговорний проиес, сеиесія, холоднии мир, компроміс, співробітництво, Придністров'я, Південна Осетія, Донбас. 